\title{
KaJian KeSESUAian MANAJEMEN BENCANa TERHADAP KoMPONEN Manajemen Bencana Pada KaWasan RaWan Bencana TanaH LONGSOR TINGGI DI KABUPATEN KARANGANYAR
}

\author{
Oktavian Cendhy Bunga Pratama, Murtanti Jani Rahayu, Rufia Andisetyana Putri \\ Program Studi Perencanaan Wilayah dan Kota, \\ Fakultas Teknik \\ Universitas Sebelas Maret, Surakarta \\ Email: oktaviancendhy@gmail.com
}

\begin{abstract}
Karanganyer regency's government has set the area - the area that potentially catastrophic landslide in Karanganyaer regency a spatial plan of karanganyar regency in 2012 -2031. The area prone to high landslide disaster has greater risk in the event of catastrophic landslide, so that the disaster management has more pay attention in the area prone to high landslide disaster. The problem in this research in how the suitability of disaster management in areas prone to landslides high Karanganyar regency towards disaster management component. The purposes of this research is to know the suitability of disaster management in areas prone to landslides high Karanganyar towards disaster management component. This research use deductive qualitative approaches. The results of this study shows in the area prone to high landslide disaster of Karanganyar regency has reached compliance. Area prone to high landslide disaster not have "early warning system" and warning light yet, but have applied conventional voice signal. Has been designated evacuation meeting point even though the capacity has not enough. Evacuation lanes using existing road network and currently there are not evacuation lanes and evacuation fringes yet. The relocation has been implemented on the residents who occurred landslide and homeless lived.
\end{abstract}

Keyword: disaster management, disaster-prone area of landslide

\section{PENDAHULUAN}

Kenyamanan pada permukiman dapat terwujud salah satunya dengan menciptakan suasana aman dan bebas dari ancaman bencana. Upaya untuk meningkatkan keamanan pada kawasan rawan bencana adalah dengan adanya manajemen bencana yang sesuai dengan kerakteristik kawasan tersebut. Pengelolaan kebencanaan bukan merupakan tindakan yang dapat dilakukan secaran incidental, melainkan merupakan kegiatan yang harus dilakukan secara terencana dengan manajemen yang baik melalui suatu proses yang disebut manajemen bencana (Ramli, 2010)

Keadaan geografis Kabupaten Karanganyar menjadi salah satu faktor terjadinya bencana longsor di Kabupaten Karanganyar. Bencana tanah longsor terjadi di Kabupaten Karanganyar secara periodik dan tidak hanya terjadi pada satu kawasan namun pada beberapa kawasan (BPBD Kabupaten Karanganyar, 2016)

Bencana longsor yang terjadi di Kabupaten Karanganyar merupakan bencana yang sudah menjadi siklus rutin (Kurniawan, 2016). Semenjak tahun 2012, beberapa wilayah di Kabupaten Karanganyar termasuk wilayah yang secara rutin terkena bencana tanah longsor baik pada wilayah permukiman maupun non permukiman.
Menurut Rencana Tata Ruang Wilayah Kabupaten Karanganyar 2012-2031, kawasan rawan bencana ditetapkan dalam dua klasifikasi yakni kawasan rawan bencana tinggi dan sedang. Kawasan rawan bencana tanah longsor tinggi Kabupaten Karanganyar perlu lebih diperhatikan dalam penanggulangan bencananya.

Manajemen bencana yang sudah diterapkan di Kabupaten Karanganyar antara lain adalah Pra Bencana, Tanggap Darurat dan Pasca Bencana (BPBD Kabupaten Karanganyar, 2016). Penelitian ini bertujuan untuk mengetahui kesesesuaian manajemen bencana pada kawasan rawan bencana tanah longsor tinggi Kabupaten Karanganyar dengan sasaran yang ditempuh: (1) Identifikasi manajemen bencana pada kawasan rawan bencana tanah longsor tinggi Kabupaten Karanganyar, (2) Analisis kesesuaian manajemen bencana pada kawasan rawan bencana tanah longsor tinggi Kabupaten Karanganyar.

\section{TINJAUAN PUSTAKA}

Manajemen bencana merupakan kegiatan terorganisasi dan terencana, oleh karena itu proses atau tahapan-tahapan manajemen bencana telah menjadi bagian yang melekat dalam manajemen bencana. Tahap-tahap manajemen bencana menjelaskan proses dalam pengurangan resiko terhadap bencana. Tahapan-tahapan tersebut pada 
umumnya terdiri atas tahap pra bencana, saat terjadi bencana atau tanggap darurat dan tahap pasca bencana (Kumalasari, 2014). Tahap pra bencana merupakan upaya-upaya yang dilakukan sebelum terjadinya bencana. Tahap tanggap darurat merupakan upaya-upaya yang dilakukan pada saat terjadinya bencana, sedangkan tahap pasca bencana merupakan upaya-upaya yang dilakukan setelah terjadinya bencana. Berdasarkan proses dalam manajemen bencana, di dalamnya terdapat komponen-komponen manajemen bencana. Komponen - komponen utama dalam tiga proses manajemen bencana tersebut antara lain adalah sistem peringatan dini, titik kumpul, lokasi evakuasi, rute dan jalur evakuasi serta relokasi.

\subsection{Sistem Peringatan Dini}

Menurut Sudarto (2007) beberapa hal yang dapat dilaksanakan dalam peringatan dini adalah pemasangan early warning system sesuai kapasitas dan lingkup bencana, pembuatan dan sosialisasi mengenai peta rawan bencana, serta upgrade prasarana dan data kebencanaan secara periodik (Sudarto KD, 2007).

\subsection{Titik Kumpul}

Titik kumpul adalah tempat yang aman dari ancaman bahaya dan dapat dengan mudah dijangkau oleh penduduk ketika terjadi bencana. Dilihat dari fungsinya, titik kumpul adalah tempat penduduk menghindari bencana untuk pertama kalinya sebelum di jemput oleh relawan ataupun pemerintah (http://etd.ugm.ac.id dalam D. S. Wibowo, 2015).

\subsection{Lokasi Evakuasi}

Lokasi evakuasi merupakan salah satu komponen yang dibutuhkan dalam manajemen bencana (Undang-Undang Nomor 24 Tahun 2007 tentang Penanggulangan Bencana, 2007). Jika lokasi itu langsung dijadikan tempat pengungsian sementara maka harus diperhitungkan juga kebutuhannya. Luasan yang dibutuhkan untuk orang dewasa dalam posisi tidur adalah $2 \mathrm{~m}^{2}$ (dua meter persegi), ditambah dengan satu meter untuk jarak yang digunakan lalu lalang. Dengan demikian setidaknya memerlukan $3 \mathrm{~m}^{2}$ (tiga meter persegi) per orang (Sawariyanto, et al., 2007).

\subsection{Jalur Evakuasi}

Jalur evakuasi diperlukan dalam proses manajemen bencana (Supriyono, 2014). Dalam mempersiapkan jalur evakuasi, sebelumnya hendaknya mempertimbangkan mengenai rute evakuasi serta rambu-rambu evakuasi. Rute evakuasi merupakan alur jalan yang dilalui penduduk menuju tempat yang lebih aman. Penentu dari efektivitas dari rute evakuasi adalah adanya rambu evakuasi yang dapat membantu korban bencana menuju lokasi pengungsian (Supriyono, 2014).

\subsection{Relokasi}

Penataan lokasi permukiman dapat dilakukan dengan langkah awal yakni pemetaan daerah rawan bencana. Dengan pemetaan daerah rawan bencana dapat menjadi pertimbangan dalam pemilihan lokasi permukiman penduduk. Permukiman padat penduduk di daerah seismic dan rawan longsor perlu dilakukan relokasi ke daerah lain yang lebih aman (Supriyono, 2014).

\section{METODE PENELITIAN}

Metode penelitian menjelaskan mengenai hal-hal teknis berkaitan dengan penelitian yang berupa ruang lingkup, variabel, metode pengumpulan data dan metode analisis.

\subsection{Ruang Lingkup}

Ruang lingkup wilayah penelitian ini merupakan kawasan rawan bencana longsor tingkat tinggi Kabupaten Karanganyar yang telah ditetapkan oleh Pemerintah Kabupaten Karanganyar dalam Rencana Tata Ruang Wilayah Kabupaten Karanganyar tahun 2012-2031. Ruang Lingkup wilayah penelitian sebagaimana terlampir dalam Lampiran 1 Gambar 1.

\subsection{Metode Analisis}

Pendekatan penelitian yang digunakan dalam penelitian ini adalah pendekatan deduktif, dengan metode kuantitatif. Variabel dan indikator dalam penelitian ini dapat dilihat dalam Lampiran 2.

Guna menunjang pemenuhan data dari variabel penelitian ini, data dapat diperoleh melalui wawancara, observasi dan studi literatur. Teknik analisis yang akan digunakan untuk mengukur tingkat kesesuaian tersebut adalah teknik analisis skoring. Analisis dilakukan pada tiap parameter untuk mengetahui pada masingmasing variabel, sehingga diketahui kelemahan dan potensi masing - masing sub - variabel dan variabel. Indikator untuk masing-masing variabel terlampir pada Lampiran 3.

Nilai-nilai masing - masing kategori dihitung berdasarkan pembagian antara nilai kesesuaian dalam setiap variabel dengan masing - masing parameter dan sub variabel. Kategori dari hasil perhitungan analisis skoring adalah sebagai berikut:

Interval $=\frac{\text { Nilai Maksimal }- \text { Nilai Minimal }}{\text { Jumlah Kelas }}$ 
Interval $=\frac{15-5}{3}$

Interval $=3,33$

Kesesuaian Tinggi: Jika Skor $11,68 \leq \mathrm{x} \leq 15$

Kesesuaian Sedang: Jika Skor 8,34 $\leq \mathrm{x} \leq 11,67$

Kesesuaian Rendah: Jika Skor $5 \leq \mathrm{x} \leq 8,33$

Sedangkan untuk penilaian terhadap tiap komponen atau tiap variabel, digunakan nilai sebagai berikut:

$\begin{aligned} \text { Interval } & =\frac{\text { Nilai Maksimal }- \text { Nilai Minimal }}{\text { Jumlah Kelas }} \\ \text { Interval } & =\frac{3-1}{3} \\ \text { Interval } & =0,67\end{aligned}$

Kesesuaian tinggi:

jika nilai $2,33 \leq \mathrm{x} \leq 3$

Kesesuaian sedang: $\quad$ jika nilai $1,67 \leq \mathrm{x} \leq 2,33$

Kesesuaian rendah: jika nilai $1 \leq \mathrm{x} \leq 1,67$

\section{HASIL DAN PEMBAHASAN}

Hasil dan pembahasan akan menjelaskan kondisi dilapangan terkait manajemen bencana yang diterapkan kemudian ditinjau terhadap literatur terkait manajemen bencana.

\subsection{Teknologi Pendeteksi Gerakan Tanah 4.1.1 Early warning system}

Kawasan rawan bencana tanah longsor tinggi Kabupaten Karanganyar yang seharusnya lebih diprioritaskan dalam pengadaan early warning system justru tidak memiliki early warning system yang terpasang. Early warning system pendeteksi bencana tanah longsor justru terpasang di luar kawasan rawan bencana tanah longsor tinggi Kabupaten Karanganyar. Early warning system yang terpasang di luar kawasan rawan bencana tanah longsor tersebut juga tidak menjangkau kawasan rawaan bencana tanah longsor tinggi Kabupaten Karanganyar. Early warning system yang telah ada dipasang setelah kawasan tersebut terjadi bencana tanah longsor atau terpantau memiliki tanah yang bergerak. Peta sebaran early warning system dapat dilihat pada Lampiran 1 Gambar 2.

\subsubsection{Penerapan Lampu Isyarat}

Lampu isyarat sebagai peringatan bencana tanah longsor teradapat pada kawasan yang memilik early warning system yang telah modern seperti ekstensometer yang terhubung dengan sirine. Sirine tersebut dapat menyalakan lampu ketika bencana tanah longsor terdeteksi oleh ekstensomenter. Pada kawasan rawan bencana tanah longsor tinggi Kabupaten Karanganyar tidak memiliki early warning system, hal tersebut juga menunjukan bahwa pada kawasan rawan bencana tanah longsor tinggi Kabupaten Karangnyar juga tidak terdapat lampu isyarat sebagai isyarat peringatan terjadinya bencana tanah longsor.

\subsubsection{Penerapan Suara Isyarat}

Isyarat suara yang diterapkan sebagai peringatan terjadinya bencana tanah longsor pada kawasan rawan bencana tanah longsor tinggi Kabupaten Karanganyar adalah pengeras suara dan kentongan. Pengeras suara ini memanfaatkan pengeras suara yang terdapat pada mushola dan masjid pada lingkungan permukiman sekitar kawasan rawan bencana tanah longsor tinggi Kabupaten Karanganyar. Sedangkan kentongan terdapat pada minimal tingkat rukun tetangga pada permukiman karena kentongan tidak hanya sebagai isyarat bencana saja maka dapat dipastikan bahwa setiap rukun tetangga memiliki satu unit kentongan.

\subsection{Titik Kumpul}

\subsubsection{Ketersediaan Titik Kumpul}

Di Kabupaten Karanganyar sendiri titik kumpul yang digunakan saat terjadinya bencana adalah lapangan seperti yang telah disampaikan oleh Badan Penanggulangan Bencana Daerah kepada masyarakat melalui sosialisasi secara langsung maupun tidak langsung. Titik kumpul yang menjadi tujuan saat terjadi bencana tanah longsor pada kawasan rawan bencana tanah longsor tinggi Kabupaten Karanganyar adalah lapangan-lapangan yang berada pada sekitar kawasan rawan bencana tanah longsor tinggi. Hal tersebut bertujuan untuk mengantisipasi lapangan-lapangan yang berada di dalam kawasan rawan bencana tanah longsor tidak dapat menampung jumlah pengungsi dan lapanganlapangan yang berada dalam kawasan rawan bencana tanah longsor diasumsikan lebih beresiko terkena bencana tanah longsor yang lebih parah dari pada kawasan sekitarnya. Peta sebaran lapangan sebagai titik kumpul dapat dilihat pada Lampiran 3 Gambar 3.

\subsection{Lokasi Evakuasi}

\subsubsection{Ketersediaan Lokasi Evakuasi}

Lokasi evakuasi ini mayoritas dijadikan untuk pengungsian sementara menggunakan fasilitas umum. Fasilitas tersebut antara lain adalah gedung-gedung sekolah mulai dari TK hingga SMA, gedung pemerintahan baik tingkat kelurahan/desa hingga kecamatan, lapangan, dan fasilitas kesehatan. Berdasarkan data dan observasi total seluruh luasan fasilitas umum fadalah sebesar $18.405,10 \mathrm{~m}^{2}$ dengan luasan tersebut dapat diketahui kemampuan daya tampung lokasi evakuasi adalah sebesar 6.135 
jiwa sedangkan jumlah seluruh penduduk pada kawasan rawan bencana tanah longsor tinggi Kabupaten Karanganyar adalah sebesar 18.811 jiwa. Hal tersebut berarti bahwa fasilitas umum yang berada pada sekitar kawasan rawan bencana tanah longsor tinggi Kabupaten Karanganyar belum memenuhi daya tampung penduduk untuk dijadikan sebagai lokasi evakuasi apabila terjadi bencana tanah longsor. Peta sebaran lokasi evakuasi dapat dilihat dalam Lampiran 3 Gambar 4.

\subsection{Rute dan Jalur Evakuasi \\ 4.4.1 Ketersediaan Rute dan Jalur Evakuasi}

Jalur evakuasi ini dapat menghubungkan antara lokasi bencana dengan titik kumpul, lokasi bencana langsung dengan lokasi evakuasi, dan titik kumpul dengan lokasi evakuasi. Sedangkan rute evakuasi merupakan alur jalur yang dapat dilalui penduduk menuju tempat yang lebih aman. Penentu dari evektifitas rute evakuasi adalah dengan adanya rambu evakuasi yang dapat membantu korban bencana menuju lokasi pengungsian. Hal - hal yang diutamakan dalam jalur evakuasi bencana tanah longsor merupakan jaringan-jaringan jalan yang mampu menghubungkan penduduk dalam pusat kegiatan penanggulangan bencana (lokasi bencana, titik kumpul dan lokasi evakuasi) tanpa mengurangi keamanan dari penggunaan jaringan jalan tersebut.

Pada kawasan rawan bencana tanah longsor tinggi Kabupaten Karanganyar, untuk saat ini belum terdapat rute evakuasi bencana tanah longsor secara khusus (Badan Penanggulangan Bencana Daerah Karanganyar 2016). Rute-rute evakuasi yang akhirnya digunakan saat proses evakuasi mayoritas ditetapkan setelah terjadi bencana kemudian relawan melakukan penyisiran jaringan jalan yang aman untuk digunakan sebagai rute evakuasi nantinya

\subsubsection{Ketersediaan Evakuasi}

Kawasan rawan bencana tanah longsor tinggi Kabupaten Karangnyar saat ini belum memiliki rambu - rambu evakuasi. Berdasarkan observasi dan wawancara Badan Penanggulangan Bencana Daerah Kabupaten Karanganyar, baik ramburambu evakuasi yang berfungsi sebagai penunjuk arah menuju lokasi evakuasi maupun ramburambu evakuasi yang menunjukkan ancaman bahaya atau hal-hal yang boleh dilakukan dan tidak seharusnya dilakukan pada sekitar kawasan rawan bencana tidak terdapat pada kawasan rawan bencana tanah longsor tinggi Kabupaten
Karanganyar (Badan Penanggulangan Bencana Daerah Kabupaten Karanganyar 2016).

\subsection{Relokasi}

\subsubsection{Sasaran Relokasi}

Relokasi pada kawasan rawan bencana tanah longsor tinggi Kabupaten Karanganyar mayoritas dilaksanakan setelah terjadinya bencana tanah longsor. Relokasi yang telah dilaksanakan pada kawasan rawan bencana tanah longsor tinggi Kabupaten Karanganyar tidak sembarangan dalam memilih sasaran relokasi. Penduduk atau permukiman yang menjadi sasaran relokasi adalah mereka yang telah terkena bencana tanah longsor. Relokasi dilaksanakan melihat beberapa kepala keluarga yang terkena dampak dari bencana tanah longsor dan biasanya lokasi relokasi tidak begitu jauh dari permukiman awalnya. Seperti relokasi yang telah terlaksana, beberapa relokasi masih dalam lingkup satu dusun, satu kelurahan, dan satu kecamatan. Jarang terjadi relokasi dengan lintas antar kecamatan atau bahkan kabupaten (Mugiyo, 2016).

\subsection{Kesesuaian Manajemen Bencana pada Kawasan Rawan Bencana Tanah Longsor Tinggi Kabupaten Karanganyar}

Kesesuaian manajemen bencana pada kawasan rawan bencana tanah longsor tinggi Kabupaten Karanganyar memiliki skor akhir sepuluh yang berarti bahwa kesesuaian manajemen bencana pada kawasan rawan bencana tanah longsor tinggi berkesesuaian sedang. Kesesuaian untuk setiap indikator maupun keseluruhan secara lebih rinci dapat dilihat dalam Lampiran 4.

\section{KESIMPULAN}

Manajemen bencana yang telah diterapkan pada kawasan rawan bencana tanah longsor tinggi Kabupaten Karanganyar telah mencapai kesesuaian sedang. Kesesuaian tersebut menurut penilaian keseluruhan manajemen bencana atau kumulatif manajemen bencana pada kawasan rawan bencana tanah longsor tinggi Kabupaten Karanganyar. Sedangkan untuk kesesuaian setiap indikatornya beberapa indikator tidak sesuai dengan manajemen bencana yang seharusnya, beberapa pula telah sesuai dan terdapat indikator yang sangat sesuai. Kondisi yang tidak sesuai tersebut antara lain dari ketersediaan early warning system yang tidak terdapat pada kawasan rawan bencana tanah longsor tinggi Kabupaten Karanganyar, belum terdapat isyarat lampu sebagai peringatan terjadinya bencana tanah longsor, kemudian belum terdapat rambu-rambu evakuasi pada kawasan rawan bencana tanah 
longsor tinggi Kabupaten Karanganyar. Komponen manajemen bencana yang telah sesuai adalah telah terdapat lokasi evakuasi namun belum memenuhi daya tampung penduduk kawasan rawan bencana tanah longsor tinggi Kabupaten Karanganyar, telah memiliki jalur evakuasi yang menggunakan jaringan jalan eksisting yang digunakan penduduk untuk melakukan kegiatan sehari-hari dan relokasi telah dilaksanakan meskipun dilaksanakan setelah terjadi bencana tanah longsor. Sedangkan beberapa indikator yang telah sangat sesuai adalah penerapan isyarat suara yang menggunakan kenthongan dan pengeras suara modern, telah tersedianya titik kumpul yang ditetapkan sebelumnya yang berupa lapangan.

\section{REFERENSI}

BPBD Kabupaten Karanganyar. (2016). Badan Penanggulangan Bencana Daerah Kabupaten Karanganyar.

Kumalasari, B. (2014). Manajemen Bencana dan Kapasitas Pemerintahan Lokal. Yogyakarta: Gava Medika.

Kurniawan. (2016). Bencana KaranganyarLereng Gunung Lawu Longsor di Beberapa Titik, Ini Dampaknya. Surakarta:

http://www.solopos.com/2016/02/08/benc ana-karanganyar-lereng-gunung-lawulongsor-di-beberapa-titik-ini-dampaknya689117.

Mugiyo. (2016, November 15). Manajemen Bencana di Lingkungan. (O. C. Pratama, Interviewer)

Peraturan Daerah Nomor 1 Tahun 2013 tentang Rencana Tata Ruang Wilayah Kabupaten Karanganyar Tahun 2013-2032. (2013). Karanganyar: Pemerintah Kabupaten Karanganyar.

Ramli, S. (2010). Pedoman Praktis Manajemen Bencana (Disaster Management). Jakarta: Dian Rakyat.

Sawariyanto, Ardiyanto, H., Windrawan, P., Silvanto, T., Qodr, Z., \& Ridwan, N. K. (2007). Panduan Penanganan Bencana Bagi Pengambil Kebijakan dan Pelaksana Program. Yogyakarta: Tim Teknis Nasional.

Sudarto KD, G. (2007). Kebijakan PEMDA Bantul tentang Mitigasi Bencana. Yogyakarta: Pusat Studi Bencana Alam (PSBA) UGM; Pemerintah Daerah (PEMDA) Bantul.
Supriyono, P. (2014). Seri Pendidikan Penanggulangan Bencana Tanah Longsor. Yogyakarta: Penerbit Andi.

Undang-Undang Nomor 24 Tahun 2007 tentang Penanggulangan Bencana. (2007).

Wibowo, D. S. (2015). Kelayakan Sistem Evakuasi Kawasan Rawan Bencana Letusan Gunung Merapi di Kabupaten Sleman (Syudi Kasus: KRB Gunung Merapi- Kabupaten Sleman). Surakarta: Program Studi Perencanaan Wilayah dan Kota Universitas Sebelas Maret Surakarta. 
Lampiran 1

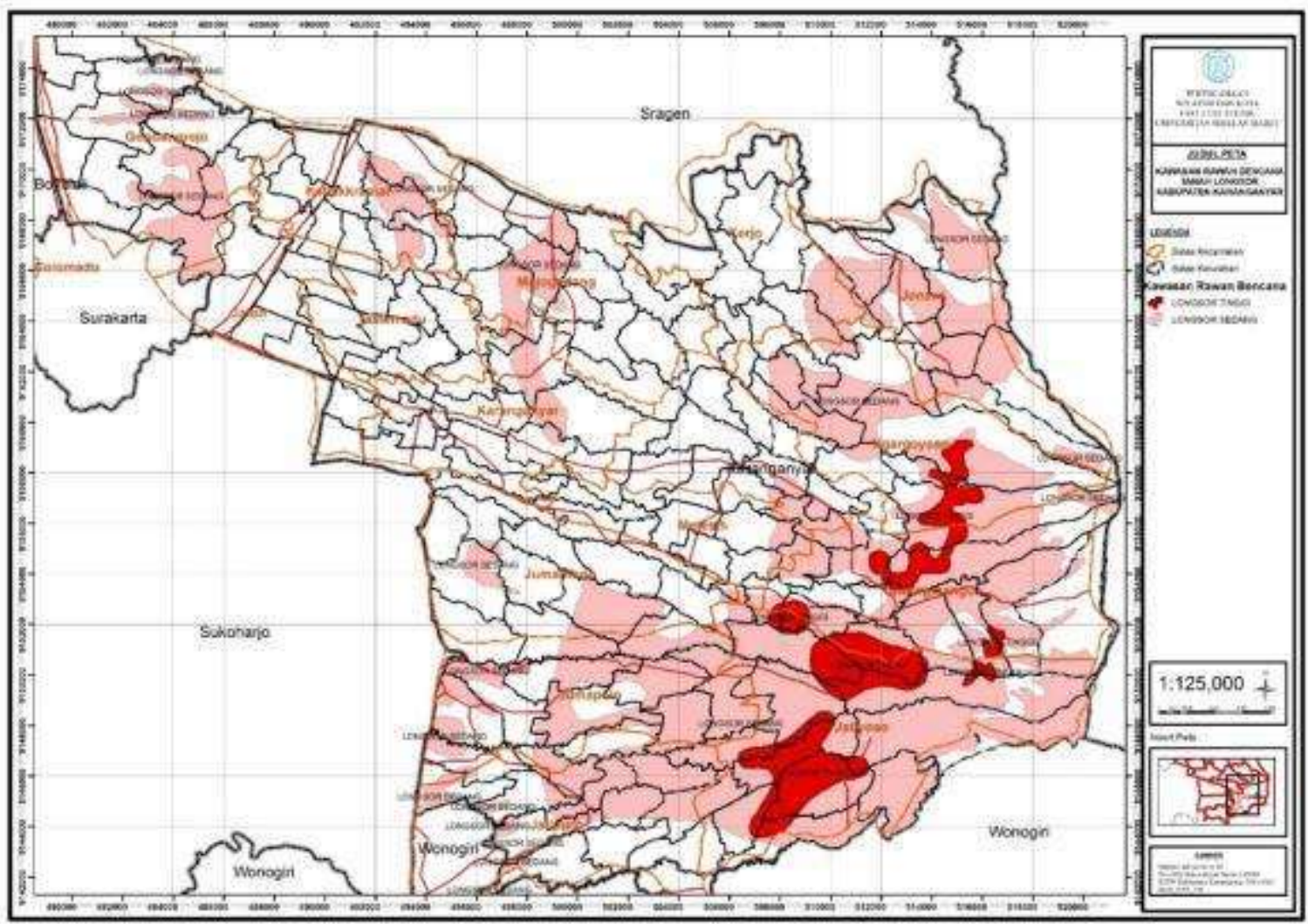

Gambar 1. Ruang Lingkup Penelitian

(Rencana Tata Ruang Wilayah Kabupaten Karanganyar, 2012-2031)

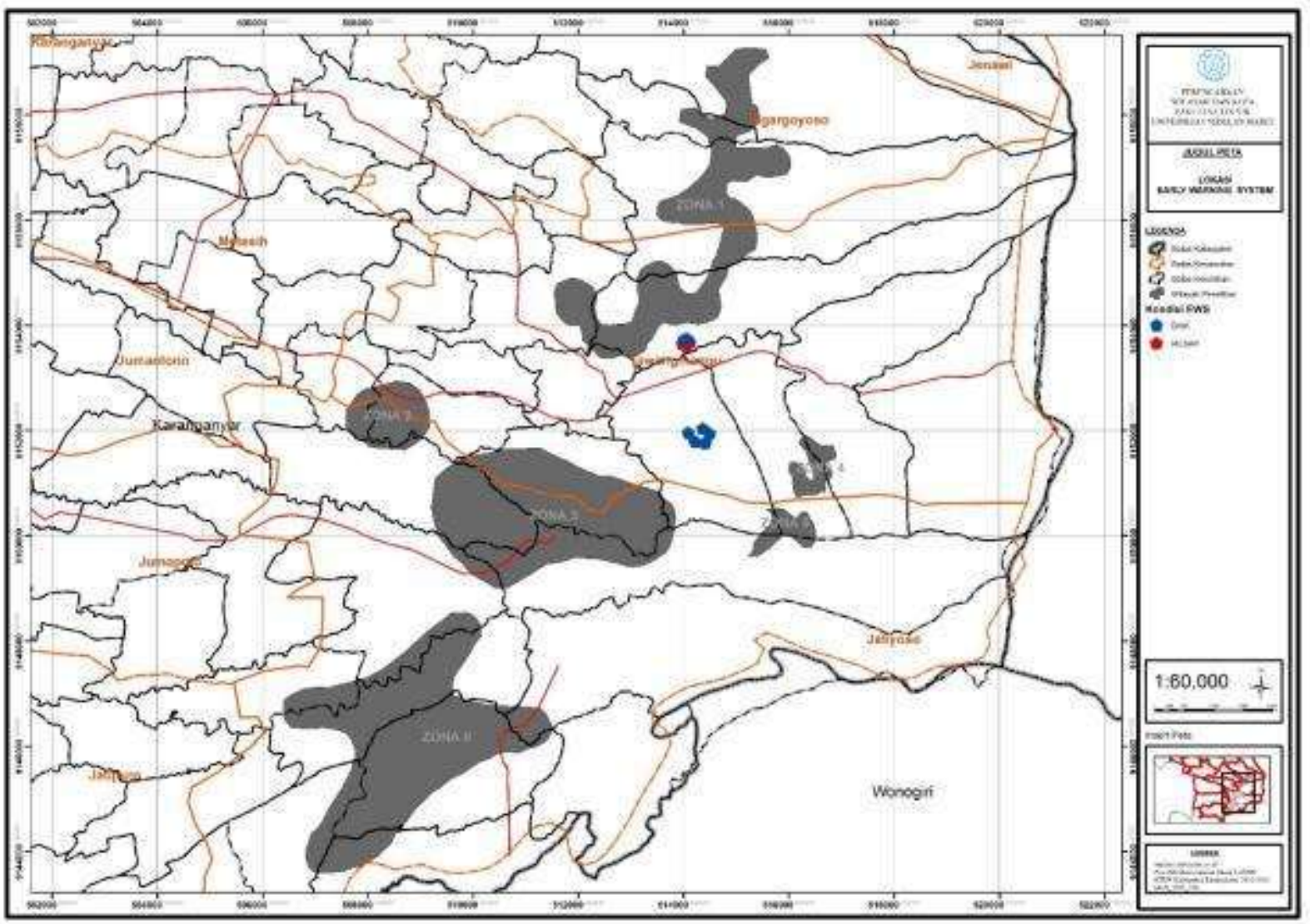

Gambar 2. Peta Sebaran Early warning system

(Badan Penanggulangan Bencana Daerah Kabupaten Karanganyar \& Survei Lapangan, 2016) 
Lampiran 2

Indikator Penilaian Kesesuaian Manajemen Bencana

\begin{tabular}{|c|c|c|c|c|c|}
\hline \multirow[t]{2}{*}{ Variabel } & \multirow[t]{2}{*}{ Subvariabel } & \multirow[t]{2}{*}{ Indikator } & \multicolumn{3}{|l|}{ Parameter } \\
\hline & & & Sangat Sesuai & Sesuai & Tidak Sesuai \\
\hline \multirow[t]{7}{*}{$\begin{array}{l}\text { Sistem } \\
\text { Peringatan } \\
\text { dini }\end{array}$} & \multirow[t]{2}{*}{$\begin{array}{l}\text { Teknologi } \\
\text { pendeteksi } \\
\text { datangnya } \\
\text { bencana }\end{array}$} & \multirow[t]{2}{*}{$\begin{array}{l}\text { Early } \\
\text { warning } \\
\text { system }\end{array}$} & $\begin{array}{l}\text { Memiliki early warning system } \\
\text { yang berfungsi dengan baik dan } \\
\text { menjangkau seluruh kawasan } \\
\text { rawan bencana tanah longsor }\end{array}$ & $\begin{array}{l}\text { Memiliki early warning } \\
\text { system namun tidak berfungsi } \\
\text { dengan baik ataupun tidak } \\
\text { menjangkau seluruh kawasan }\end{array}$ & $\begin{array}{lr}\text { Tidak } & \text { memiliki } \\
\text { early } & \text { warning } \\
\text { system } & \end{array}$ \\
\hline & & & $1 \frac{1}{2}$ & 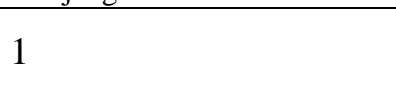 & $\frac{1}{2}$ \\
\hline & \multirow[t]{5}{*}{$\begin{array}{l}\text { Teknologi } \\
\text { isyarat } \\
\text { peringatan }\end{array}$} & \multirow[t]{3}{*}{$\begin{array}{l}\text { Penerapan } \\
\text { Lampu } \\
\text { Isyarat }\end{array}$} & $\begin{array}{lcr}\text { Terdapat } & \text { lampu } & \text { isyarat } \\
\text { datangnya } & \text { bencana } & \text { yang } \\
\text { berfungsi dengan baik dan } \\
\text { menjangkau seluruh kawasan }\end{array}$ & $\begin{array}{lr}\text { Terdapat lampu } & \text { isyarat } \\
\text { datangnya bencana } & \end{array}$ & $\begin{array}{l}\text { Tidak terdapat } \\
\text { isyarat lampu }\end{array}$ \\
\hline & & & 3 & & 1 \\
\hline & & & $\overline{4}$ & $\overline{4}$ & $\overline{4}$ \\
\hline & & \multirow[t]{2}{*}{$\begin{array}{l}\text { Penerapan } \\
\text { Isyarat } \\
\text { Suara }\end{array}$} & $\begin{array}{l}\text { Terdapat isyarat suara datangnya } \\
\text { bencana yang berfungsi dengan } \\
\text { baik dan menjangkau seluruh } \\
\text { kawasan }\end{array}$ & $\begin{array}{l}\text { Terdapat isyarat suara } \\
\text { datangnya bencana }\end{array}$ & $\begin{array}{lr}\text { Tidak } r \text { terdapat } \\
\text { isyarat } & \text { suara } \\
\text { datangnya bencana }\end{array}$ \\
\hline & & & & & $\frac{1}{1}$ \\
\hline \multirow{3}{*}{$\begin{array}{l}\text { Titik } \\
\text { Kumpul }\end{array}$} & \multirow{3}{*}{$\begin{array}{l}\text { Titik } \\
\text { Kumpul }\end{array}$} & \multirow{3}{*}{$\begin{array}{l}\text { Ketersediaan } \\
\text { Titik } \\
\text { Kumpul }\end{array}$} & Terdapat titik kumpul yang telah & Tersedia titik kumpul saat & Tidak terdapat \\
\hline & & & ditentukan sebelum bencana & terjadi bencana & titik kumpul \\
\hline & & & 3 & 2 & 1 \\
\hline \multirow[t]{2}{*}{$\begin{array}{l}\text { Lokasi } \\
\text { evakuasi }\end{array}$} & \multirow[t]{2}{*}{$\begin{array}{l}\text { Lokasi } \\
\text { evakuasi }\end{array}$} & \multirow[t]{2}{*}{$\begin{array}{l}\text { Ketersediaan } \\
\text { Lokasi } \\
\text { Evakuasi }\end{array}$} & $\begin{array}{l}\text { Tersedia lokasi evakuasi yang } \\
\text { mampu menampung seluruh } \\
\text { korban terdampak bencana tanah } \\
\text { longsor }\end{array}$ & $\begin{array}{lr}\text { Tersedianya lokasi } & \text { evakuasi } \\
\text { namun belum } & \text { cukup } \\
\text { menampung } & \text { korban } \\
\text { terdampak bencana } & \\
\end{array}$ & $\begin{array}{l}\text { Tidak Tersedianya } \\
\text { lokasi evakuasi }\end{array}$ \\
\hline & & & 3 & 2 & 1 \\
\hline \multirow[t]{4}{*}{$\begin{array}{l}\text { Jalur } \\
\text { evakuasi }\end{array}$} & \multirow[t]{2}{*}{$\begin{array}{l}\text { Rute dan } \\
\text { jalur } \\
\text { evakuasi }\end{array}$} & \multirow{2}{*}{$\begin{array}{l}\text { Ketersediaan } \\
\text { rute dan } \\
\text { jalur } \\
\text { evakuasi }\end{array}$} & $\begin{array}{l}\text { Tersedianya rute dan jalur } \\
\text { evakuasi }\end{array}$ & Tersedianya jalur evakuasi & $\begin{array}{l}\text { Tidak } \\
\text { rute dan jaluredianya } \\
\text { evakuasi }\end{array}$ \\
\hline & & & $1 \frac{1}{2}$ & 1 & $\frac{1}{2}$ \\
\hline & \multirow[t]{2}{*}{$\begin{array}{l}\text { Rambu- } \\
\text { rambu } \\
\text { evakuasi }\end{array}$} & \multirow{2}{*}{$\begin{array}{l}\text { Ketersediaan } \\
\text { rambu- } \\
\text { rambu } \\
\text { evakuasi }\end{array}$} & $\begin{array}{l}\text { Tersedianya rambu-rambu } \\
\text { evakuasi dalam keadaan baik }\end{array}$ & \begin{tabular}{llr} 
Tersedianya & \multicolumn{2}{c}{ rambu-rambu } \\
evakuasi namun tidak \\
berfungsi dengan baik
\end{tabular} & $\begin{array}{l}\text { Tidak Tersedianya } \\
\text { rambu-rambu } \\
\text { evakuasi }\end{array}$ \\
\hline & & & $1 \frac{1}{2}$ & 1 & $\frac{1}{2}$ \\
\hline \multirow[t]{2}{*}{ Relokasi } & \multirow[t]{2}{*}{ Relokasi } & \multirow[t]{2}{*}{$\begin{array}{l}\text { Sasaran } \\
\text { Relokasi }\end{array}$} & $\begin{array}{l}\text { Dilaksanakan relokasi pada } \\
\text { seluruh permukiman }\end{array}$ & Dilakukan relokasi sebagian & $\begin{array}{l}\text { Tidak } \\
\text { dilaksanakan } \\
\text { relokasi } \\
\end{array}$ \\
\hline & & & 3 & 2 & 1 \\
\hline
\end{tabular}




\section{Lampiran 3}

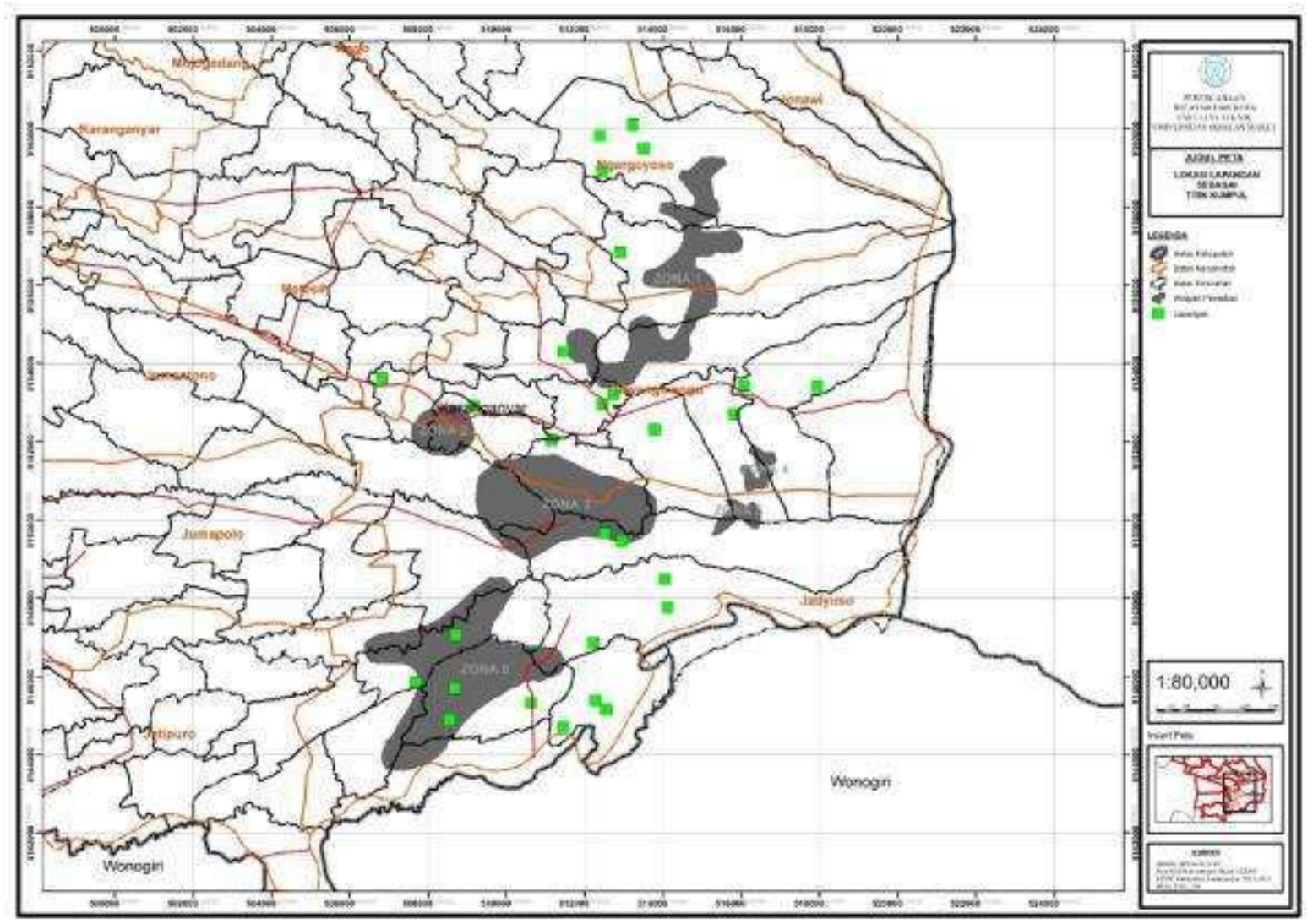

Gambar 3. Peta Sebaran Lapangan sebagai Titik Kumpul

(Badan Penanggulangan Bencana Daerah Kabupaten Karanganyar \& Survei Lapangan, 2016)

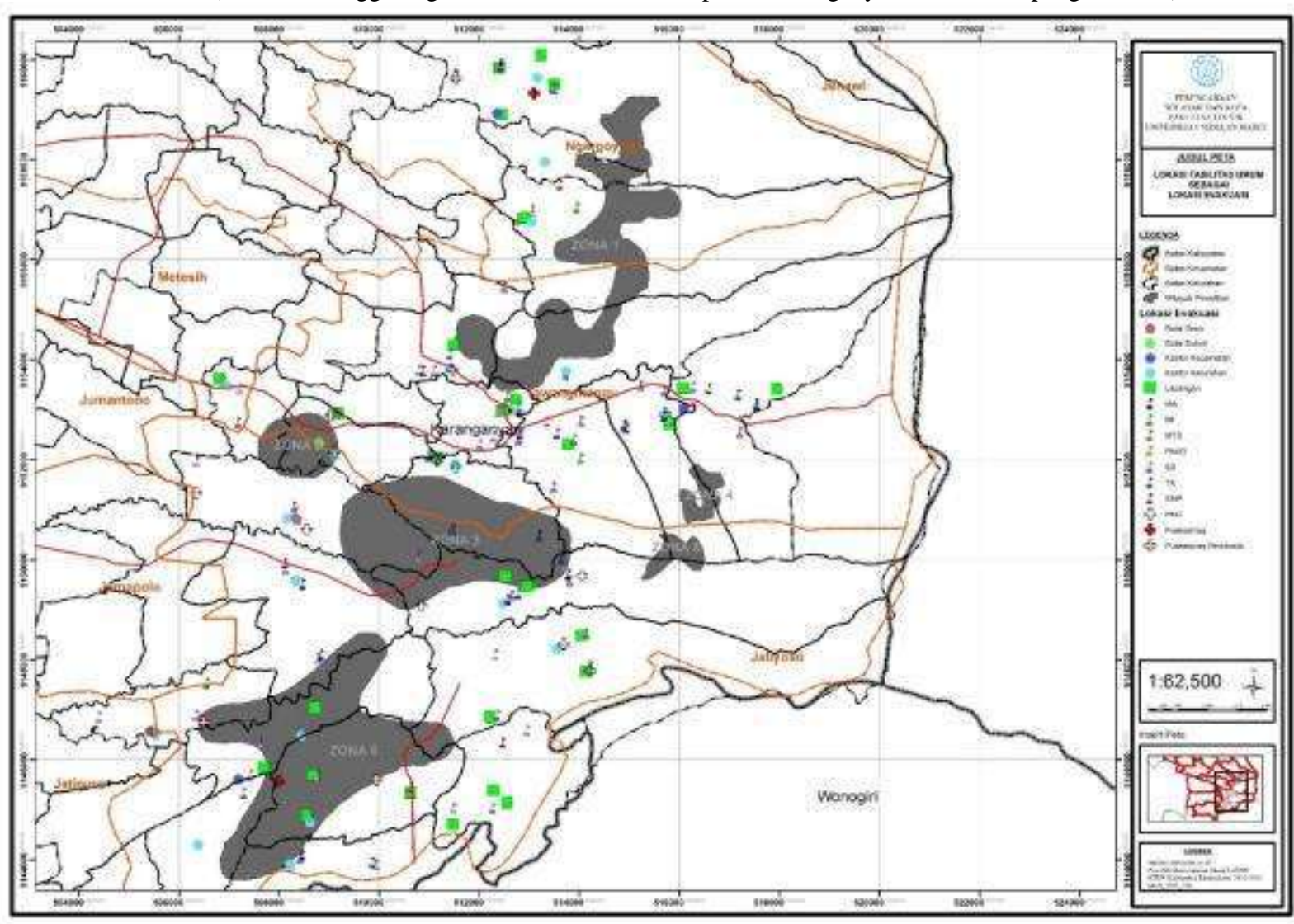

Gambar 4. Peta Sebaran Fasilitas Umum sebagai Lokasi Evakuasi

(Badan Penanggulangan Bencana Daerah Kabupaten Karanganyar \& Survei Lapangan, 2016) 


\section{Lampiran 4}

Tabel Kesesuaian Keseluruhan Manajemen Bencana

\begin{tabular}{|c|c|c|c|c|c|c|}
\hline Variabel & $\begin{array}{l}\text { Sub- } \\
\text { Variabel }\end{array}$ & Parameter & Manajemen Bencana Eksisting & $\begin{array}{l}\text { Kesesuaian } \\
\text { Komponen }\end{array}$ & Skor & $\begin{array}{l}\text { Kesesuaian } \\
\text { Variabel }\end{array}$ \\
\hline \multirow[t]{3}{*}{$\begin{array}{l}\text { Sistem } \\
\text { Peringatan } \\
\text { dini }\end{array}$} & $\begin{array}{l}\text { Teknologi } \\
\text { pendeteksi } \\
\text { datangnya } \\
\text { bencana }\end{array}$ & Early warning system & $\begin{array}{l}\text { Kawasan rawan bencana tanah longsor } \\
\text { tinggi Kabupaten Karanganyar Itidak } \\
\text { memiliki early warning system yang } \\
\text { terpasang. Early warning system yang } \\
\text { dipasang diluar kawasan rawan bencana } \\
\text { tanah longsor tinggi Kabupaten } \\
\text { Karanganyar tidak menjangkau kawasan } \\
\text { rawaan bencana tanah longsor tinggi } \\
\text { Kabupaten Karanganyar. }\end{array}$ & $\begin{array}{l}\text { Tidak } \\
\text { Sesuai }\end{array}$ & $\frac{1}{2}$ & $\begin{array}{l}\text { Kesesuaian } \\
\text { Rendah }\end{array}$ \\
\hline & \multirow[t]{2}{*}{$\begin{array}{l}\text { Teknologi } \\
\text { isyarat } \\
\text { peringatan }\end{array}$} & $\begin{array}{l}\text { Penerapan Lampu } \\
\text { Isyarat }\end{array}$ & $\begin{array}{l}\text { Pada kawasn rawan bencana tanah } \\
\text { longsor tinggi Kabupaten Karangnayar } \\
\text { juga tidak terdapat lampu isyarat } \\
\text { sebagai isyarat peringatan terjadinya } \\
\text { bencana tanah longsor }\end{array}$ & $\begin{array}{l}\text { Tidak } \\
\text { Sesuai }\end{array}$ & $\frac{1}{4}$ & \\
\hline & & $\begin{array}{l}\text { Penerapan Isyarat } \\
\text { Suara }\end{array}$ & $\begin{array}{l}\text { Isyarat suara yang diterapkan sebagai } \\
\text { peringatan terjadinya bencana tanah } \\
\text { longsor pada kawasan rawan bencana } \\
\text { tanah longsor tinggi Kabupaten } \\
\text { Karanganyar adalah pengeras suara dan } \\
\text { kentongan. }\end{array}$ & $\begin{array}{l}\text { Sangat } \\
\text { Sesuai }\end{array}$ & $\frac{3}{4}$ & \\
\hline $\begin{array}{l}\text { Titik } \\
\text { Kumpul }\end{array}$ & $\begin{array}{l}\text { Titik } \\
\text { Kumpul }\end{array}$ & $\begin{array}{l}\text { Ketersediaan Titik } \\
\text { Kumpul }\end{array}$ & $\begin{array}{l}\text { Di Kabupaten Karanganyar sendiri titik } \\
\text { kumpul yang digunakan saat terjadinya } \\
\text { bencana adalah lapangan. Lapangan } \\
\text { digunakan karena memiliki area yang } \\
\text { cukup luas dan dapat digunakan } \\
\text { manufer kendaraan-kendaraan yang } \\
\text { akan memindahkan korban bencana dari } \\
\text { titik kumpul menuju lokasi evakuasi. }\end{array}$ & $\begin{array}{l}\text { Sangat } \\
\text { Sesuai }\end{array}$ & 3 & $\begin{array}{l}\text { Kesesuaian } \\
\text { Tinggi }\end{array}$ \\
\hline $\begin{array}{l}\text { Lokasi } \\
\text { evakuasi }\end{array}$ & $\begin{array}{l}\text { Lokasi } \\
\text { evakuasi }\end{array}$ & $\begin{array}{l}\text { Ketersediaan Lokasi } \\
\text { Evakuasi }\end{array}$ & $\begin{array}{l}\text { Fasilitas umum yang berada pada } \\
\text { sekitar kawasan rawan bencana tanah } \\
\text { longsor tinggi Kabupaten Karanganyar } \\
\text { belum memenuhi daya tampung } \\
\text { penduduk untuk dijadikan sebagai } \\
\text { lokasi evakuasi apabila terjadi bencana } \\
\text { tanah longsor. }\end{array}$ & Sesuai & 2 & $\begin{array}{l}\text { Kesesuaian } \\
\text { Sedang }\end{array}$ \\
\hline \multirow[t]{2}{*}{$\begin{array}{l}\text { Jalur } \\
\text { evakuasi }\end{array}$} & $\begin{array}{l}\text { Rute dan } \\
\text { jalur } \\
\text { evakuasi }\end{array}$ & $\begin{array}{l}\text { Ketersediaan rute dan } \\
\text { jalur evakuasi }\end{array}$ & $\begin{array}{l}\text { Pada kawasan rawan bencana tanah } \\
\text { longsor tinggi Kabupaten Karanganyar, } \\
\text { untuk saat ini belum terdapat rute } \\
\text { evakuasi bencana tanah longsor secara } \\
\text { khusus. Jalur evakuasi bencana tanah } \\
\text { longsor merupakan jaringan-jaringan } \\
\text { jalan. }\end{array}$ & Sesuai & 1 & \multirow[t]{2}{*}{$\begin{array}{l}\text { Kesesuaian } \\
\text { Rendah }\end{array}$} \\
\hline & $\begin{array}{l}\text { Rambu- } \\
\text { rambu } \\
\text { evakuasi }\end{array}$ & $\begin{array}{l}\text { Ketersediaan rambu- } \\
\text { rambu evakuasi }\end{array}$ & $\begin{array}{l}\text { Kawasan rawan bencana tanah longsor } \\
\text { tinggi Kabupaten Karangnyar saat ini } \\
\text { belum memiliki rambu-rambu } \\
\text { evakuasi. }\end{array}$ & $\begin{array}{l}\text { Tidak } \\
\text { Sesuai }\end{array}$ & $\frac{1}{2}$ & \\
\hline Relokasi & Relokasi & Sasaran Relokasi & $\begin{array}{l}\text { Relokasi yang telah dilaksanakan pada } \\
\text { kawasan rawan bencana tanah longsor } \\
\text { tinggi Kabupaten Karanganyar tidak } \\
\text { sembarangan dalam memilih sasaran } \\
\text { relokasi. Penduduk atau permukiman } \\
\text { yang menjadi sasaran relokasi adalah } \\
\text { mereka yang telah terkena bencana } \\
\text { tanah longsor. }\end{array}$ & Sesuai & 2 & $\begin{array}{l}\text { Kesesuaian } \\
\text { Sedang }\end{array}$ \\
\hline Jumlah & & & & & 10 & $\begin{array}{l}\text { Kesesuian } \\
\text { Sedang }\end{array}$ \\
\hline
\end{tabular}

